\title{
Teachers' and Students' Perceptions of Teaching Games for Understanding Approach in Physical Education Lessons 體育教阨和中學生對領會教學法的教學觀感
}

\author{
Alberto CRUZ \\ Department of Physical Education \& Sports Science, \\ Hong Kong Institute of Education, HONG KONG \\ 高達倫 \\ 香港敎育學院體育及運動科學系
}

\begin{abstract}
The purpose of this study was to investigate teachers' and students' perceptions toward the implementation of teaching games for understanding (TGFU) approach to teaching team handball lessons. The paper is intended to help serving teachers decide whether to adopt this approach in their teaching. The participants were five secondary physical education teachers and their secondary one to three students. The teachers were briefed the principles of the TGFU approach and instructed to teach with an eight-lesson team handball unit lesson plans in TGFU approach. A post-teaching interview on their views of using the new approach was conducted with the teachers. Views of students on their perceptions toward the effectiveness of the instructional approach were obtained through the use of a questionnaire at the end of the unit. Results revealed that all teachers held positive views on TGFU approach. They were willing to adopt this approach in future as the students were more active and had more fun in the lessons. The students expressed they had learnt well by understanding more about the tactics and the rules of the games. The positive responses of teachers and students to TGFU have great implications for teacher education and development.
\end{abstract}

\section{摘 要}

本研究目的是探討體育敉師和中學生對領會敉學法教授手球課的觀感。研究員希望本文能協助在職老師審視利用領會敉學法敉學 的可行性。五位中學體育老師及其初中學生參與是次研究。研究員首先向體育老師介紹領會敉學法的敉學原則, 其後他們參照領會敉 學法手球單元敉案敉授八節手球課。老師在授課後接受研究員訪問, 探究他們對實施領會呚學法的意見。研究員亦利用問卷收集學生 對此呚學法的效能觀感。結果顯示老師對領會呚學法持正面評價及樂於使用此敉學策略。學生亦表示透過此呚學法使他們更認識球例 及戰術運用。此等正面回饋給予敎師發展及培訓多方面的啟示。

\section{Introduction}

Games activities have been well perceived by school children. Western studies indicated that school students preferred games to other alternative sport activities in their school lessons and extra-curricular activities (Luke \& Sinclair, 1991; Strand \& Scantling, 1994; Tannehill \& Zakrajsek, 1993; Williams \& Woodhouse, 1996). Hong Kong school children are no exceptions, some recent local studies also showed that Hong
Kong students would like to participate in games activities in leisure time and choose games activities as their favourite sports participating activities ( $\mathrm{Fu}, 1993$; Hong Kong Sports Development Board, 2003; Lindner, 1998; Ng, 1996).

Indeed, games have occupied a significant part in physical education curriculum. Physical educators have indicated that games teaching have received a disproportionate allocation of time in physical education curriculum (Werner, Thorpe, 
\& Bunker, 1996; Williamson, 1982). By analyzing the syllabus for Hong Kong primary school physical education issued by the Curriculum Development Council (1995), Liu (1995) commented that nearly $30 \%$ of the suggested physical education curriculum time is allocated to games. Li (1996) also pointed out that team games engaged almost half of the major teaching activities of secondary curriculum by most Hong Kong secondary physical education teachers in his study. It is likely that games have taken a lion's share of teaching and learning time in physical education classes in both Hong Kong and overseas.

As games are a large part of the physical education, physical education teachers have long been concerned the appropriate approach to teaching games activities. The traditional technique-based approach to teaching games has been criticized ineffective and considered problematic (Bunker \& Thorpe, 1982). The approach was condemned that placing much emphasis on physical capacities rather than an understanding of the overall dynamics of game play (Grehaigne \& Godbout, 1995). From the results of his survey, Liu (1995) indicated that 92. 9\% of 155 Hong Kong secondary physical education teachers are currently adopting the technique-based approach in games teaching and show no tendency in changing their teaching approach. It seems that most physical education teachers in Hong Kong are used to adopting the technique-based approach in teaching games activities. On the other hand, some recent studies investigating the effectiveness of the teaching games for understanding (TGfU) approach seem to give promising results and suggest the importance of the understanding approach to games teaching (Gabriele \& Maxwell, 1995; Griffin, Oslin, \& Mitchell, 1995; Mitchell, Griffin, \& Oslin, 1997; Rink, French, \& Graham, 1996).

The Teaching Games for Understanding approach to games teaching was originated by Bunker and Thorpe (1982) as they were dissatisfied with the quality of the 'traditional' technical and skill driven nature games teaching approach they observed. They argued that the "traditional" approach was failing to help children acquiring skills, games knowledge and ability in making effective decisions during game play. Bunker and Thorpe (1982) proposed a tactical awareness model of teaching games that put the games at the focus of the teaching and learning process. This approach emphasizes on developing tactical knowledge and the understanding of "what to do" within game contexts should precede development of specific skill of 'how to do'. The approach is supported by those who have tested it and show its benefits in improving game performance by providing link between skills and tactics within game context (Doolittle \& Girard, 1991; Mitchell, Griffin, \& Oslin, 1994, 1997; Sibson, 1992; Smith, 1991; Turner \& Martinek, 1995; Werner \& Almond, 1990).

The Teaching Games for Understanding Approach is indeed well taken by many physical education teachers. Butler (1996) reported that there were a number of positive outcomes from using TGfU approach compared to those teaching with techniqueoriented approach from the responses of ten experienced physical education teachers. The students were more on task, spent more time in small group interactions as well as more involved in their own decision-making. The teaching and learning process had changed its focus to the development of student understanding and the construction of meaning of the students in the classes taught by the TGfU approach.

In another study of perceptions held by two middle school physical education teachers about the TGfU and technique approaches in teaching field hockey for 13 weeks, Turner (1996) stated that both teachers perceived their students were lack of enthusiasm for the learning tasks and deteriorated in technique levels during game play when taught by the technique-based approach. The teachers suggested that the TGfU approach enhanced the students' abilities to think as it focused on problem solving and questioning.

Four Hong Kong secondary physical education teachers also presented favourable responses after they had adopted the TGfU approach in teaching a six-hour unit volleyball to 140 school children (Liu \& Thorpe, 1997). The teachers enjoyed and recognized the value of the teaching approach. The school children gained enjoyable experiences as well and gave favourable comments such as interesting, exciting, stimulating, refreshing, and reporting greater understanding and increased in ability and confidence to describe their subjective feelings of this approach.

Recently, Light (2002a) studied the perceptions of preservice generalist primary school teachers on learning and teaching the TGfU approach. Many of those interviewed believed that this approach would allow them to teach confidently and to provide enjoyable and equitable experiences of games to their students. Three pre-service teachers reported that they had positive experiences of teaching TGfU approach. They felt that their first attempts had been successful in terms of student participation and enjoyment. 
Lately, local schoolteachers are advised to use different learning and teaching strategies to meet the different abilities, interests and needs of the students in order to achieve the different purposes of learning in the recent educational reform movement (Curriculum Development Council, 2001). As the findings of these TGfU studies were positive and encouraging, it is worthwhile for the local physical education teachers to reconsider the teaching approach to games teaching. However, Brooker, Kirk and Braiuka (2000) reported that there might be challenges when implementing the TGfU approach to teaching physical activity when they studied a junior high school physical education teacher adopting the TGfU teaching basketball in a naturalistic setting. The major challenge identified was the different perceptions and the acceptance of the TGfU approach by both the teaching professionals and students. Therefore, the TGfU approach to games teaching is examined and how it is perceived by the local secondary physical education teachers and students in this paper. The purposes of this paper are twofold: To examine the perceptions of five physical education teachers and their students toward the TGfU approach in handball lessons and to understand the difficulties the teachers may face when adopting the TGfU approach in teaching. This information intends to help the serving teachers decide whether to use the TGfU approach in their methodologies of games teaching.

\section{Methods}

\section{Subjects}

The participants for this study were five secondary school physical education teachers ( 4 males and 1 female) ranging in age from 26 to 40 years and 392 secondary one to three students. The participants were purposely invited to take part in the study as they have rich background knowledge and experience in teaching team games. Permissions were also sought from their school principals and consent forms were completed by the five teachers. All teachers obtained their Qualified Teacher Status and were trained locally in teaching physical education. Their physical education teaching experiences ranged from 3 to 16 years and they were rich in ball games knowledge background as coaching either team handball or basketball in their respective schools. They claimed that they were familiar with the traditional technique-based approach and only adopted this approach in teaching ball games lessons. The male teachers and the female teacher are responsible to teach boys and girls in their schools physical education lessons respectively.

\section{Data Collection}

The five teachers were required to attend a TGfU training session before the start of the study. They were briefed the principles of the implementation of the TGfU approach and watched the video of the workshop conducted by Rod Thorpe (the originator of the TGfU approach) in teaching the use of TGfU approach in games lessons. The researcher explained and answered the questions raised by the teachers after the briefing session. They were then provided an eight-lesson team handball unit lesson plans in TGfU approach prepared by the researcher and were asked to teach the lessons to two classes of their students. Data were collected once the teachers had started their teaching. The teachers were asked to keep a reflective journal that focused on their perceptions about the process of implementation the TGfU approach as well as the reactions of the students to this teaching approach in the lessons. A post-teaching in-depth interview was conducted with each teacher individually. An interview guide approach (Patton, 1990) was adopted. A set of open-ended questions was developed to use as a guide during the interview as to ensure all pre-set topics were covered with every teacher. Responses were probed as the need arose. The list was used to help focus on their views of using the TGfU approach in their teaching and to gather the richest information from the participants. All the interviews took place at the researcher's office and were carried out in a situation that avoided the possibility of interruption that encouraged the interviewees to express their opinions. The interviews were audiotaped and later transcribed verbatim for analysis. All interviews lasted between 50 to 60 minutes. Views of students were also obtained through the use of a structured questionnaire with open-ended questions at the end of the teaching unit. These questions focused on the students' perceptions toward the effectiveness of the instructional approach. The content validity of the student questionnaire was developed by consulting two experienced physical education teacher education researchers in the Institute of Education. Final version of the student questionnaire was agreed by the two experts. In fact, a pilot use of the interview questions and students' questionnaires were carried out. A secondary school physical education teacher who had tried the TGfU approach in his physical education lessons was interviewed and his 10 students were asked to fill in the questionnaires. The data collected during this pilot run indicated that the interview questions and students' questionnaire were valid for the study. As the teachers raised that they had problems in collecting survey questionnaires from all student participants. It was compromised that 25 student participants from each school were randomly selected to fill in the student questionnaires. 112 questionnaires were returned and the response rate was $89.6 \%$ 


\section{Data Analysis}

Data were organized and analyzed through inductive analysis and constant comparison (Denzin \& Lincoln, 1994; Miles \& Huberman, 1994). Transcripts from individual interviews and student questionnaires were reviewed, re-read and analyzed. Categories that arose frequently were combined to form themes.

For the purposes of enhancing the trustworthiness of the data, the following procedures were employed. First, all data were triangulated which helps to increase the consistency of the data. This also ensures the use of multiple data sources in a study (Patton, 1990). Data from the interview, reflective journals and questionnaires were compared and contrasted to cross check interpretation. Second, member checks (Patton, 1990) were used for the interview data. Teachers were asked to correct errors or inaccuracies in the transcripts. They were also asked to read the transcriptions and verify what had been said. As themes emerged from the data, they were checked with teachers for comments and validation. There was no substantive change by the teachers. Third, a peer debriefing was also used to maximize data trustworthiness (Lincoln \& Guba, 1985). A colleague familiar with qualitative methodologies was invited to read and comment the preliminary analysis. His role is to challenge the biases and interpretations of the data of the researcher as well as the methodological procedures adopted during the analytic process.

\section{Resullts and Discussion}

The major purpose of this study was to understanding the perception of five physical education teachers and their students toward the TGfU teaching approach. Data analysis indicated that the perceptions of the five teachers were based on the following categories: (a) instructional experience, (b) students reaction, and (c) teaching feasibility. While the responses of the students were categorized into three themes: (a) positive perception, (b) enhance learning and (c) ideal approach.

\section{Perception of Secondary School Teachers towards TGfU Approach}

\section{Instructional Experience}

The perception of the new teaching approach in this study mainly based on the actual teaching experience of the teachers within their handball lessons. Schoolteachers will accept the teaching approach if they do not have much difficulties and receive the positive outcomes during the lessons. All five teachers highly valued the new approach after they had tried it. The following quotes from the interviews were some of the comments from the physical education teachers:

I find that the TGfU is a student-center learning approach. The student would learn through participating in activities. Learning activities of this approach are rich, meaningful and in variety. (Teacher $A$ )

The approach is stimulating and it guides students to learn. (Teacher B)

The TGfU is fresh and systematic to me. (Teacher C)

To me the TGfU is a new challenge and the students may learn and progress differently during their learning. (Teacher D)

I agree that this is an alternative method to teaching games lessons and I have no problem during the implementation of this approach. I accept this teaching strategy in games lessons other than the direct teaching method. (Teacher E)

Besides, the approach seemed to be well accepted by the physical education teachers. They had given merits of the approach:

I find that the approach offers more participating opportunities and learning for the students. The students will involve more in the learning activities. (Teacher A)

This approach helps me to identify the students' different learning abilities. I may help them according to their needs. (Teacher B)

As there is limited direction given by the teachers, the students take the initiatives in learning in the lessons. They have more freedom in making decisions during their learning. This is a good training for them. The students then have more opportunity to develop their potential. (Teacher C)

The approach offers and improves student motives to learn. This is a kind of self-learning initiative strategy. (Teacher D)

The students comparatively more involved in the learning activities. Their activity levels were high. They seemed to be more interested in the learning activities. This approach may arouse their interest to learn and create dense learning atmosphere in class. (Teacher E) 


\section{Students Reaction}

The extent of students' reaction to the teaching approach may also affect how the teachers perceive the values of the TGfU. If the students' learning behaviours and outcomes have improved under the new teaching approach, the teachers will definitely regard the strategy as valuable and effective. Interview data indicated that the students positively responded to the teaching approach from the teachers' perspectives. From the observation of the teachers, the students were more active, excited and happier in the learning activities when compared to their reaction taught by traditional technique-based approach.

The students seemed to be happy and enjoyed in the games activities designed for them. They were more actively participating in the learning activities. (Teacher B)

The students liked to respond to the questions and involved in the games activities. As they had less restriction, the students had more opportunities to express their views. They looked happier in TGfU when compared to their performances in traditional direct teaching approach. (Teacher D)

They seemed to accept this teaching approach as they enjoyed the games.....they also had more opportunities in applying their learned skills in games situations. (Teacher E)

Data shown in the teachers' reflective journals also provided evidences that the students had changed their learning behaviours under the new teaching approach. The following episodes gave the examples of the students learning behaviours in the lessons:

The students actively responded to my questions, this was out of my expectation. I should have given more chance for them to express their views..... they actively participated in the games and seemed that they were enjoying in the learning activities. (Teacher B)

The students had more interaction in the lessons as they had more opportunity to communicate to each other during the games activities. Obviously these learning activities enhance students' cooperation. (Teacher C)

I was not sure whether the students had improved their skills, but I was definitely sure they all had chance to apply their skills in games situations. I trusted that they had gained some game skills under this learning environment. Overall, they seemed to get much pleasure from these learning activities. (Teacher E)

\section{Teaching Feasibility}

Teachers will adopt the new teaching approach again only when they recognize the usefulness of the approach as well as finding no difficulty when implementing. Although the teachers in the present study admitted they had some difficulties when implementing the new approach, they had confidence and were willing to use this approach in teaching other games activities. When they were further asked about the ways of resolving these difficulties in future teaching, most of them could provide reasonable tackling strategies. It seems that the teachers will resolve these itechnicalî problems if they have more experience in adopting this new approach. The following were the teaching difficulties they mentioned when using the TGfU approach:

I sometimes found that I had problems in allocation space for the games activities. Besides, the approach also took me some extra time in grouping the students and organizing the activities. For the benefits of the students, I ought to shorten the management time in future. (Teacher B)

Comparatively speaking, I spent less time in teaching the skills. I didn't know whether this was right or wrong. (Teacher C)

It seemed that there was not enough time for them (students) to learn in the games activities. Sometimes, the students' learning might not progress as scheduled and planned. The most difficult situation I had ever met was the lowmotivation students. They were reluctant to participate in the learning activities. I usually allocated some active students to the group and helped these less initiative students to take part in the games activities. (Teacher E)

Moreover, all teachers expressed that they had confidence in adopting this teaching approach in future. They claimed that they would give better teaching performance if they had better planning and preparations. As the teachers found the TGfU helped to arouse the learning interest of the students, they were willing to replicate this teaching strategy in other games lessons.

Of course, I have confidence in using the TGfU. With the help of my ball games coaching knowledge, I will take this approach as an alternative strategy in games teaching. (Teacher A)

Since the students like this teaching approach, I will definitely use this teaching approach again. (Teacher C)

I agree that this approach will help to develop tactical awareness. Besides, it also arouses the learning interest 
of the students. I will try this approach in other games activities during the physical education lessons. (Teacher E)

Apparently, for the benefits of the students, the physical education teachers will use the TGfU approach again in teaching other ball games lessons. Indeed, how the students perceive and react to the teaching approach in classes will influence the teachers' decisions in adopting the approach in future. The responses of the students in the post-lesson questionnaires did serve this purpose as to provide information how they viewed the teaching approach. After analyzing the data, the following three themes of the students' responses toward TGfU emerged in the survey questionnaires: Positive perception, enhance learning and ideal approach.

\section{Responses of Students towards the TGfU Approach}

\section{Positive Perception}

About $65 \%$ of the respondents identified that the teachers had changed their teaching approach when compared to their usual teaching styles in games lessons. Some of the major features of the changes mentioned were a) they played more games in the lessons, b) the games activities were introduced first, then the teacher intervened and games practice followed, c) they sensed that they had learnt through the games activities. Besides, 95\% of the respondents had positive impression on the TGfU approach. They described their experiences in the games lessons taught by this approach as new and challenging. They had fun and enjoyed the activities. They found the learning activities were exciting and interesting. Compared to their teachers' traditional teaching styles, they felt that they had more learning time. Some students even said that they had more freedom and less restriction under this teaching approach. They preferred to learn in this environment. The results obtained are also consistent to previous studies that students in the TGfU approach reported increased enjoyment when learning (Griffin, Oslin, \& Mitchell, 1995; Light, 2003; Liu \& Thorpe, 1997). It is likely the learning atmosphere created by the TGfU approach did provide some positive emotional experience of the game in which the students participated. This may explain why most of them give favourable impression of this approach. Physical educators should aware the importance of this learning medium in related to the learning games in physical education lessons.
Moreover, about $90 \%$ of the respondents expressed that they liked the teachers adopting the TGfU approach in teaching handball lessons. The five major reasons they gave were a) this approach helped them understand the games easier and they learned faster, b) they could experience and participate in more games activities and learned the games, c) this approach was fun and interesting, d) the approach was new and fresh to them, and e) it involved more thinking in the lessons (see Table 1).

Table 1. Major Reasons for Students Like their Teachers to Adopt TGfU Approach in Teachingto Adopt TGfU Approach in Teaching Handball.

Major Reasons

No. of Students Responded

1. Easy to understand and learn faster 35

2. Participate in games and learn the games 22

3. More fun and interesting 12

4. New and fresh 7

5. Involves thinking 5

There were also about $76 \%$ of the respondents expressed that they would like their teacher to use TGfU approach again in teaching other games activities in their physical education lessons. The reasons were similar to those why they liked their teachers using TGfU in teaching handball: (a) the approach would help them to have more understanding and learn faster, (b) the approach was interesting and fun, (c) they had more chance to participate in games, (d) the activities were flexible and attractive, and (e) they felt free and relax in this learning environment (see Table 2).

Table 2. Major Reasons for Students Like their Teachers to Adopt TGfU Approach in Teaching Other Games Activities.

Major Reasons

No. of Students Responded

1. Understand more and learn faster 33

2. Fun and interesting 15

3. More chance participating in games 14

4. Flexible and attractive 7

5. Free and relax 4 
Apparently, the students felt that they understand and learn faster under the TGfU settings. Light (2002b) argued that students develop much of their understanding and games skills through interaction in games within the TGfU approach. By emphasizing cognitive learning in and through game, students increase their depth of engagement through the learning involved. It is not surprising that the students claim they learn better under this environment.

\section{Enhance Learning}

Teachers are always concerned the appropriate teaching approach in meeting the needs of the students and helps their learning. The students in the present study reflected that the TGfU approach had enhanced their learning in games lessons. They claimed that they understood more about the game introduced and the rules and regulations related; acquired the techniques required for the game play; could apply the games tactics and be more confidence in playing the game (see Table 3).

Table 3. Major Areas Students Claimed that TGfU Approach Had Improved their Learning in Games.

\begin{tabular}{lc}
\hline Major Areas & No. of Students Responded \\
\hline 1. Understand more about the game & 88 \\
2. Learn the techniques & 84 \\
3. Rules and regulations & 77 \\
4. Apply the tactics in games & 89 \\
5. Be more confidence in playing games & 79 \\
\hline
\end{tabular}

When the students were asked about the factors they thought that had contributed to their learning in this teaching approach, the common answers given by the students were that (a) they had learnt the games skills through the participation in games activities, (b) the games situations had helped them learn easier and understand more about the dynamic nature of the game, and (c) good teaching performances given by the teachers. In short, the students held favourable views and believed that the TGfU approach had benefited their learning in games lessons. Light \& Fawn (2003) comment that the TGfU approach in game teaching offers educator a practical means through which they can provide a holistic learning experience for student centered on the body. It helps to develop games skills as well as developing appropriate decision-making ability. From the students' viewpoints, the TGfU approach did enhance their 'total experiences of games' and learning within games or game-like activities.

\section{Ideal Approach}

As there are different approaches in teaching, teachers always want to know which teaching approach benefits most to their students. Teaching is a complex activity and contextual in nature, it seems that there is no one best approach to suit all students and teaching environments. Therefore, some teachers would like to know what teaching approach their students would like them to adopt in their lessons. This information might help the teachers to decide the appropriate teaching activities and meet the needs of the students. In the present study, the students were asked to describe the ideal teaching approach in games lessons. There were about $37 \%$ of the respondents chose playing more games and $27 \%$ of the respondents named TGfU as the ideal approach. The other major characteristics of the ideal approach described by the students were shown in Table 4 .

Table 4. Major Characteristics Mentioned by the Students in Their Ideal Teaching Approach in Games Lessons.

\section{Major Characteristics No. of Students Responded}

1. Play more games 41

2. TGfU approach 30

3. Teachers playing with them 6

in the lessons

4. Traditional approach 6

5. Fun and relax 5

The data indicated in the questionnaires reflected that students liked engaging in games activities in their physical education lessons. They preferred playing more games or choosing to participate in the games-focus learning environment which TGfU approach provided. The students expressed that they would have more fun and enjoyment within these learning activities. It is likely that fun and enjoyment are the main motivators that help their learning in games lessons. No wonder why scholar and practitioners agree and consider fun as an important attainable outcome for students in physical education (O' Reilly, Tompkins, \& Gallant, 2001; Siedentop, 1996). 


\section{Implications}

Although the data generated in the present study only represent the views of five physical education teachers and 392 lower forms secondary students, findings still hold several implications for the practice of physical education. Since the teachers who had tried the TGfU gave positive views and comments on the new approach, it seemed that they held affirmative impression toward it. In fact, other physical education teachers who had adopted this approach in teaching also gave similar views and experience (Butler, 1996; Liu \& Thorpe, 1997; Light, 2002a). All the teacher participants in these studies raised that they would like to try this approach again. This implied the approach was highly valued and well received by the front line practitioners.

In practice, the physical education teachers raised that they did face some difficulties when first trying this approach. However, they showed that they had confidence in overcoming these problems if they prepared the lesson better. It is likely that trying new teaching approach in the lesson is not without problems. To help physical education teachers to cope with these unexpected difficulties, Education and Manpower Bureau or teacher education institutes should conduct TGfU in-service training workshops. As Liu (1995) suggested that more workshops should be introduced to the physical education teachers in order to let them get more familiar with this approach. If the teachers can be trained before they use the approach, they will have more confidence and more willing to try it in their daily teaching.

On other hand, most students also expressed that they would like their teachers to adopt the TGfU approach teaching other games activities again. It seems that the students prefer this learning environment in games lessons as they have experienced more fun and enjoyment. This implies that there is a strong desire for the students to play games in the physical education lessons. Moreover, the students also claimed that they had learnt better in this approach. Physical education researchers maintain that enjoyment in games arises from the experiences of achievement that relates to the development of a sense of worth and belonging (Hastie, 1998; O' Reilly, Tompkins, \& Gallant, 2001; Portman, 1995). This signifies that the TGfU approach is recognized as effective instructional strategy and well accepted by the school students. For the benefits of the students, physical education teachers should rethink their teaching approach in games lessons.
The readers need to be cautious when interpreting the results in the present study as it is only small-scaled with limited participants. Besides, the researcher has no chance to verify the TGfU approach adopted by the physical education teachers although their students sensed their teaching had changed. Therefore, it is advisable to replicate the study with more ample size of teachers and students. The teachers' teaching lessons should be videotaped and their teaching approach would then be verified.

Lastly, as the TGfU studies seem to provide promising results in games teaching, teacher education institute should also provide training for their pre-service student teachers in adopting the TGfU approach in teaching games lessons. Preservice student teachers should be encouraged to try this approach during their teaching practice. Local physical education researchers should conduct more study and develop teaching materials related to the teaching of TGfU. This helps the local physical education teachers understand more about the TGfU approach.

All in all, the results in the present study indicated the TGfU approach was recognized and accepted by the five physical education teachers and their students. The TGfU approach is definitely an alternative approach in teaching games activities. It is time for the local physical education teachers to review their approach in teaching games lessons!

\section{References}

Brooker, R., Kirk, D., \& Braiuka, S. (2000). Implementing a game sense approach to teaching junior high school basketball in a naturalistic setting. European Physical Education Review, 6(1), 7-26.

Bunker, D., \& Thorpe, R. (1982). A model for the teaching of games in the secondary school. Bulletin of Physical Education, 18(1), 5-8.

Butler. J. (1996). Teacher responses to Teaching Games for Understanding. Journal of Physical Education, Recreation and Dance, 67(1), 28-33.

Curriculum Development Council. (1995). Syllabus for Primary Schools: Syllabus for P.E. (Primary 1-6). The Government Printer, Hong Kong. 
Curriculum Development Council. (2001). Learning to learn: Life-long learning and whole-person development. The Government Printer, Hong Kong.

Denzin, N. K., \& Lincoln, Y. S. (1994). Handbook of qualitative research. Thousand Oaks, CA: Sage.

Dickenson, B., \& Sparkes, A. (1988). Pupil definitions of physical education. British Journal of Physical Education Research Supplement, 2, 6-7.

Doolittle, S., \& Girard, K. (1991). A dynamic approach to teaching games in elementary PE. Journal of Physical Education, Recreation and Dance, 62(4), 57-62.

Fu, F. H. (1993). The development of sport culture in the Hong Kong Chinese. Hong Kong: Hong Kong Baptist College.

Gabriele, T., \& Maxwell, T. (1995). Direct versus indirect methods of squash instruction. Research Quarterly for Exercise and Sport, 66(Suppl.), A-63.

Grehaigne, J. F., \& Godbout, P. (1995). Tactical knowledge in team sports from a constructivist and cognitivist perspective. Quest, 47(4), 490-505.

Griffin, L., Oslin, J., \& Mitchell. S. (1995). An analysis of two instructional approaches to teaching net games. Research Quarterly for Exercise and Sport, 66(Suppl.), A-64.

Hastie, P. (1998). The participation and perception of girls within a unit of sport Education. Journal of Teaching in Physical Education, 17(2), 157-171.

Hong Kong Sports Development Board. (2003). Sports participation survey: 2001. Research Department: Hong Kong Sports Development Board.

$\mathrm{Li}, \mathrm{C}$. (1996). The teachers'view on planning and implementation of secondary school physical education curriculum in Hong Kong. Paper presented at the 13th HKERA Annual Conference, Hong Kong.

Light, R. (2002a). The social nature of games: Australian preservice primary teachers' first experiences of Teaching Games for Understanding. European Physical Education Review, 8(3), 286-304.
Light, R. (2002b). Engaging the body in learning: Promoting cognition in games through TGfU. ACHPER Healthy Lifestyles Journal, 49(2), 23-26.

Light, R. (2003). The joy of learning: Emotion and learning in games through TGfU. Journal of Physical Education New Zealand, 36(1), 93-108.

Light, R., \& Fawn, R. (2003). Knowing the game: Integrating speech and action in games teaching through TGfU. Quest, 55(2), 161-176.

Lincoln, Y. S., \& Guba, E. G. (1985). Naturalistic inquiry. Beverly Hills, CA: Sage.

Lindner, K. J. (1998). Sport and activity participation of Hong Kong school children and youth-Part 1. The Hong Kong Journal of Sports Medicine and Sports Science, 6, 17 28.

Liu, Y. K. (1995). Games teaching: Changed or unchanged. Paper presented at the 12th HKERA Annual Conference, Hong Kong.

Liu, Y. K., \& Thorpe, R. D. (1997). The introduction of a cognitive approach to games teaching in Hong Kong. AIESEP Proceedings, pp. 125-130.

Luke, M. D., \& Sinclair, G. D. (1991). Gender differences in adolescents' attitudes toward school physical education. Journal of Teaching in Physical Education, 11(1), 3146.

Miles, B. M., \& Huberman, A. M. (1994). Qualitative data analysis: An expanded sourcebook ( $2^{\text {nd }}$ ed.). Thousand Oaks, CA: Sage.

Mitchell, S., Griffin, L., \& Oslin, J. (1994). Tactical awareness as a developmentally appropriate focus for the teaching of games in elementary and secondary physical education. The Physical Educator, 51(1), 21-28.

Mitchell, S., Griffin, L., \& Oslin, J. (1997). Teaching invasion games: A comparison of two instructional approaches. Pedagogy in Practice, 3(2), 56-69.

Ng, J. (1996). Physical activity profiles of Hong Kong secondary school children. Physical Education \& Recreation Review, 2(1), 41-48. 
O'Reilly, E., Tompkins, J., \& Gallant, M. (2001). They ought to enjoy physical activity, you know?: Struggle with fun in physical education. Sport, Education and Society, 6 (2), 211-221.

Patton, M. Q. (1990). Qualitative evaluation and research method ( $\left.2^{\text {nd }} e d.\right)$. Beverly Hills, CA: Sage.

Portman, J. (1995). Who is having fun in physical education classes? Experiences of sixth grade students in elementary and middle schools. Journal of Teaching in Physical Education, 14(4), 445-447.

Rink, J., French, K, E., \& Graham, K, C. (1996). Implications for practice and research. Journal of Teaching in Physical Education, 15(4), 490-502.

Sibson, A. (1992). An approach to games teaching in the National Curriculum. British Journal of Physical Education, 23(2), 15-17.

Siedentop, D. (1996). Physical education and education reform: the case of sport education. In S. J. Silverman \& C. D. Ennis (Eds.), Student learning in physical education (pp. 247-267). Champaign, IL: Human Kinetics.

Smith, M. D. (1991). Utilizing the games for understanding model at the elementary school level. The Physical Educator, 48(3), 184-187.

Strand, B., \& Scantling, E. (1994). An analysis of secondary student preferences towards physical education. The Physical Educator, 51(1), 119-131.

Tannehill, D., \& Zakrajsek, D. (1993). Student attitudes towards physical education: A multicultural study. Journal of Teaching in Physical Education, 13(1), 78-85.

Turner, A. (1996). Teachers' perceptions of technical and tactical models of instruction. Research quarterly for Exercise and Sport, March supplement, A90.

Turner, A., \& Martinek, T. J. (1995). Teaching for understanding: A model for improving decision making during game play. Quest, 47(1), 44-63.

Werner, P., \& Almond, L. (1990). Models of games education. Journal of Physical Education, Recreation and Dance, 61(4), 23-27.
Werner, P., Thorpe, R., \& Bunker, D. (1996). Teaching games for understanding: Evolution of a model. Journal of Physical Education, Recreation and Dance, 67(1), 2833.

Williams, A., \& Woodhouse, J. (1996). Delivering the discourseUrban adolescents' perception of physical education. Sport, Education and Society, 1(2), 201-213.

Williamson, T. (1982). A critical look at the games curriculum. Bulletin of Physical Education, 18(1), 23-26.

\section{Correspondence:}

\author{
Alberto Cruz \\ Department of Physical Education \& Sports Science, \\ Hong Kong Institute of Education, \\ Tai Po, \\ HONG KONG
}

